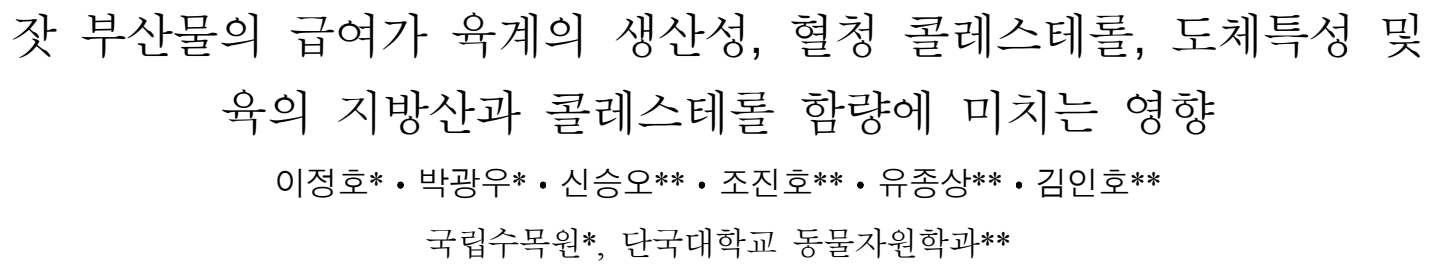

\title{
Effects of Dietary Pine Cone Meal on Growth Performance, Serum Cholesterol, Carcass Quality and Fatty Acid Composition and Cholesterol Content of Meat in Broiler Chickens
}

\author{
J. H. Lee*, K. W. Park*, S. O. Shin**, J. H. Cho**, J. S. Yoo** and I. H. Kim** \\ Korea National Arboretum*, Department of Animal Resource \& Science, Dankook University**
}

\begin{abstract}
This study was conducted to evaluate effects of dietary pine cone meal on growth performance, serum cholesterol, carcass quality and fatty acid composition and cholesterol content of meat in broiler chickens. Three treatments were assigned to 480 (2 days) Arbor Acre broiler chicks with eight replications, allocating 20 broiler chicks in each replication. Dietary treatments included 1) CS (1\% cottonwood sawdust), 2) PCM0.5 ( $0.5 \%$ cottonwood sawdust $+0.5 \%$ pine cone meal) and 3$)$ PCM1.0 (1\% pine cone meal). During the overall period the difference of growth performance was not significant among treatments $(P>0.05)$. Also, cholesterol profile (total, HDL, LDL cholesterol and triglyceride) in serum and carcass characteristic were not affected by treatments $(P>0.05)$. TBARS of leg and breast meat was significantly decreased $(P<0.05)$ in PCM1.0 treatment compared to CS treatment. In fatty acid contents of leg meat, C20:0 was significantly higher in PCM0.5 treatment than PCM1.0 treatment $(P<0.05)$. Also, C18:3n3 was significantly lower in PCM1.0 treatment than other treatments $(P<0.05)$. Cholesterol contents of leg, breast meat and abdomen fat were not significant among treatment $(P>0.05)$. In conclusion, results of the experiment were affected by dietary supplementation of pine cone meal on TBARS of leg and breast meat.
\end{abstract}

(Key words : Pine cone meal, Growth performance, TBARS, Fatty acid, Broiler)

$$
\text { I. 서 론 }
$$

최근 국제 유가의 상승은 곡물을 이용한 대 체연료의 개발을 가속화하여 수급 불안으로 인 한 가격의 폭등은 사료의 $80 \%$ 이상을 수입 원 료에 의존하고 있는 국내 양계산업에 총체적인 위기감을 주고 있다. 이러한 위기를 극복하기 위한 하나의 방안으로 국내 부존자원을 이용하
여 사료의 이용성을 높이고, 축산물의 품질을 향상시키고자 하는 연구들이 활발히 진행되고 있다.

산업 부산물은 최근 생산량이 점차 늘어나는 실정이며, Kwak과 Yoon(2003)은 각종 부산물을 부존 사료 자원으로서 재활용하여 저비용으로 고품질 축산물 생산을 위한 시도가 활발히 이 루어지고 있다고 하였다. 그러나 수집, 처리 및

Corresponding author : I. H. Kim, Dept. of Animal Resource \& Science, Dankook University \#29 Anseodong, Cheonan, Choongnam 330-714, Korea.

Tel : 041-550-3652, Fax : 041-550-3604, E-mail : inhokim@dankook.ac.kr 
경제적 이유로 활용되지 못하여 폐기되는 대부 분의 산업 부산물은 환경오염원으로 방치되고 있는 실정이다. 따라서, 산업 부산물의 활용은 사료 자원 확보 및 환경오염 감소 등 다양한 측면에서 바람직하다고 사료된다.

농림부 통계에 의하면 2005년 현재 국내에서 는 2,680 톤의 잣이 생산되고 있으며 (농림부, 2006), 잣은 수확 후 잣 알갱이만 식용으로 사 용된다. 그 외의 부산물은 그대로 버려져 환경 오염원으로 방치 되고 있기 때문에 효과적인 재활용 방법에 대한 연구가 필요한 실정이다.

잣은 지방질 함량이 높고, 잣에 함유된 지방 은 linoleic acid(48.6\%), oleic acid (22.8\%), arachidonic acid (14.4\%) 등의 불포화 지방산으 로 이루어져 있다 $(\mathrm{Kim}$ 등, 1984). 이들 불포화 지방산은 피부를 아름답게 하고 혈압을 떨어뜨 리며 스태미나를 강화시키는 (천석조와 박영호, $1984)$ 고 칼로리 식품으로 알려져 있다. 잣에는 레시틴이 많이 함유되어 있으며, 레시틴은 양 질의 불포화지방산으로서 뇌와 혈관에 좋은 성 분으로 고혈압, 당뇨병 등의 원인이 되는 동맥 경화를 예방하고 치료하는 역할을 한다 (Park과 Chung, 2005).

잣나무 진에는 terpenoid계 성분, phenol계 성 분, 타닌 및 알카로이드 성분이 함유되어 있으 며(Hong 등, 2002), terpinolene과 borneol 성분은 담즙분비를 촉진하여 콜레스테롤 수치를 낮추 는 작용을 하는 것으로 알려져 있다 $(\mathrm{Kim}$ 등, 1986). 잣나무에서 생산되는 잎과 송이는 체내 유익한 high density lipoprotein(HDL) 콜레스테 롤이 증가되어 동맥경화증 예방에 효과가 있다 고 전해지고 있으며, 일본에서는 항산화제로서 의 기능이 있는 것으로 알려지고 있다(고용균 등, 2006). 잣나무에는 영양물질 이외에 항균 (Cimanga 등, 2002), 살충효과(Baricevic 등, 2001) 및 타감 작용을 하는 약리적인 성분들이 함유되어 있으며, 이러한 화학성분은 피부자극 제, 소염제, 소독제, 완화제 및 보향제로 이용 되고 있다(Lim 등, 2001; Yang 등, 2002).

본 시험에서 사용된 잣 부산물은 정유물질을 추출한 후 남은 것으로 계육의 품질 향상에 도 움이 되는 여러 생리활성 물질들이 함유되어
있으므로, 천연활성물질인 잣 부산물을 활용할 경우 육계의 생산성 향상은 물론 계육의 품질 이 향상 될 것으로 기대된다.

따라서, 본 시험에서는 잣 부산물을 급여하 여 육계의 생산성, 혈청 콜레스테롤, 육질특성 및 육의 지방산과 콜레스테롤 함량에 미치는 영향을 알아보기 위하여 실시하였다.

\section{․ 재료 및 방법}

\section{1. 시험동물 및 시험설계}

본 시험은 2 일령 평균체중이 $44.89 \pm 0.06 \mathrm{~g}$ 인 Arbor Acre broiler(소) 480수를 공시하였으며, 5 주간 사양시험을 실시하였다.

시험 설계는 1) CS (1\% cottonwood sawdust), 2) $\mathrm{PCM} 0.5 \quad(0.5 \%$ cottonwood sawdust $+0.5 \%$ pine cone meal) 및 3) PCM1.0 (1\% pine cone meal)로 3 개 처리를 하여 처리당 8 반복, 반복당 20수씩 완전임의 배치하였다.

\section{2. 시험사료와 사양관리}

Arbor Acre broiler(상) 병아리는 평사로 가로, 세로 및 높이가 각각 $1 \mathrm{~m}$ 인 $1 \mathrm{~m}^{3}$ 크기의 24개 케이지에 20수씩 사육하였으며, 24시간 점등하 였다. 사육온도는 시험 개시시 $33 \pm 1{ }^{\circ} \mathrm{C}$ 로 맞추 어준 뒤 한 주마다 $2{ }^{\circ} \mathrm{C}$ 씩 감소시켜 시험 종료 시 $24^{\circ} \mathrm{C}$ 를 유지하였다. 기초사료는 옥수수 대 두박 위주의 crumble 형태로서 전기 2주에는 일반 기초 사료를 급여하였고, 후기 3 주는 시 험사료를 급여하였으며(Table 1), 시험사료는 옥수수-대두박 위주의 pellet 형태로서 사료의 대사 에너지는 $3,050 \mathrm{kcal} / \mathrm{kg}$, 조단백질 $19.00 \%$, lysine $1.00 \%$, Ca $0.90 \%$ 및 P $0.75 \%$ 를 함유하였 다. 사료와 물은 자유 채식토록 하였다.

\section{3. 잣 부산물의 제조 방법 및 조성}

잣 부산물은 8 월 중순부터 10 월에 수확한 것 으로 식용으로 사용하는 잣과 (주한일랩테크에 서 제작한 열수추출 장치를 이용하여 시료 1 
Table 1. Diet composition (as-fed basis)

\begin{tabular}{|c|c|c|c|c|}
\hline \multirow{2}{*}{ Ingredient (\%) } & \multirow{2}{*}{$\begin{array}{c}\text { Starter } \\
(0 \sim 2 \mathrm{wks})\end{array}$} & \multicolumn{3}{|c|}{ Finisher (2-5wks) } \\
\hline & & $\mathrm{CS}$ & PCM0.5 & PCM1.0 \\
\hline Corn & 55.67 & 62.16 & 62.16 & 62.16 \\
\hline Soybean meal (CP 48\%) & 28.25 & 24.66 & 24.66 & 24.66 \\
\hline Corn gluten meal (CP 60\%) & 6.50 & 3.50 & 3.50 & 3.50 \\
\hline Soybean oil & 5.50 & 4.89 & 4.89 & 4.89 \\
\hline Tricalcium phosphate & 2.46 & 2.29 & 2.29 & 2.29 \\
\hline Cottonwood sawdust & - & 1.00 & 0.50 & - \\
\hline Pine cone meal & - & - & 0.50 & 1.00 \\
\hline Limestone & 0.89 & 0.75 & 0.75 & 0.75 \\
\hline Salt & 0.20 & 0.20 & 0.20 & 0.20 \\
\hline Vitamin premix ${ }^{1)}$ & 0.20 & 0.20 & 0.20 & 0.20 \\
\hline Trace mineral premix ${ }^{2)}$ & 0.20 & 0.20 & 0.20 & 0.20 \\
\hline DL-methionine & 0.07 & 0.07 & 0.07 & 0.07 \\
\hline L-lysine- $\mathrm{HCl}$ & 0.06 & 0.08 & 0.08 & 0.08 \\
\hline \multicolumn{5}{|l|}{ Chemical composition ${ }^{3)}$} \\
\hline ME (kcal/kg) & 3,100 & & 3,050 & \\
\hline Crude protein $(\%)$ & 22.00 & & 19.00 & \\
\hline Lysine (\%) & 1.10 & & 1.00 & \\
\hline Methionine + Cysteine (\%) & 0.80 & & 0.78 & \\
\hline Calcium (\%) & 1.00 & & 0.90 & \\
\hline Non phytate phosphate (\%) & 0.80 & & 0.75 & \\
\hline
\end{tabular}

1) Provided per kilogram of diet: 15,000 IU of vitamin A, 3,750 IU of vitamin $\mathrm{D}_{3}, 37.5 \mathrm{mg}$ of vitamin $\mathrm{E}, 2.55 \mathrm{mg}$ of vitamin $\mathrm{K}_{3}, 3 \mathrm{mg}$ of vitamin $\mathrm{B}_{1}, 7.5 \mathrm{mg}$ of vitamin $\mathrm{B}_{2}, 4.5 \mathrm{mg}$ of vitamin $\mathrm{B}_{6}, 24 \mathrm{~g}$ of vitamin $\mathrm{B}_{12}, 51 \mathrm{mg}$ of niacin, $1.5 \mathrm{mg}$ of folic acid, $126 \mathrm{~g}$ of biotin and $13.5 \mathrm{mg}$ of pantothenic acid.

2) Provided per kilogram of diet: $37.5 \mathrm{mg}$ of $\mathrm{Zn}, 37.5 \mathrm{mg}$ of $\mathrm{Mn}, 37.5 \mathrm{mg}$ of Fe, $3.75 \mathrm{mg}$ of $\mathrm{Cu}, 0.83 \mathrm{mg}$ of I, $0.23 \mathrm{mg}$ of Se and $62.5 \mathrm{mg}$ of $\mathrm{S}$.

${ }^{3)}$ Calculated values.

$\mathrm{kg}$ 당 증류수 $5 \mathrm{~L}$ 를 넣어 $100^{\circ} \mathrm{C}$ 에서 2 시간동안 정유물질을 추출하고 남은 잣껍질, 잣송이 및 잣나뭇잎 등의 부산물을 실온에서 건조시킨 후 분말의 형태로 곱게 분쇄하였으며, 이때 건조 감량은 약 $9 \%$ 수준이었다. 본 시험에서 사용한 잣 부산물의 일반조성은 건물 함량이 $87 \%$, 조 회분 함량이 $20.34 \%$ 및 $4882.10 \mathrm{~g} / \mathrm{cal}$ 의 에너지 를 함유하였다.

\section{4. 조사항목 및 방법}

(1) 증체량, 사료섭취량 및 사료요구율 증체량은 시험 개시시, 2 주째와 시험 종료시
에 각각 측정하였다. 사료 섭취량은 체중 측정 시 사료 급여량에서 잔량을 제하여 산출하였으 며, 사료요구율은 사료섭취량을 증체량으로 나 누어 산출하였다.

\section{(2) 혈액성상}

혈액 채취는 사양시험 종료시에 처리당 임의 로 10 수씩을 선발하여 익정맥에서 주사기를 이 용하여 혈액을 $5 \mathrm{~mL}$ 채취한 후 vacuum tube (Becton Dickinson Vacutainer Systems, Franklin Lakes, NJ)에 넣어 $4^{\circ} \mathrm{C}$ 에서 $2,000 \times \mathrm{g}$ 로 30 분간 원심 분리하여 얻은 혈청을 분석에 이용하였 다. 분리된 혈청은 enzymatic colorimetric 
method (Allain et al., 1974)에 의하여, 총 콜레스 테롤 농도는 총 콜레스테롤 검사 시약(Boehringer Mannhein, Germany)에, $\mathrm{HDL}$ 콜레스테롤 농도는 HDL-C 검사 시약 (Boehringer Mannhein, Germany) 를 이용하였다. TG(Trig- lycerides) 농도는 triglyceride kit (Boehringer Mannhein, Germany)에 반응시켜 자동 생화학 분석기 (HITACHI 747, Hitachi, Japan)를 이용하여 측정하였다. Low density lipoprotein (LDL) + very low density lipoprotein(VLDL) 콜레스테롤 농도는 Naoyuki 와 Yoshiharu(1995)의 방법에 따라 평가하였 다.

(3) 도체율 및 육질분석

도체율 분석을 위하여 각 처리구별로 10 수씩 선발하여 도축하였다. 머리, 깃털, 다리 및 내 장을 적출하여 도체율을 측정하였으며, 가슴살, 다리살 및 복강지방을 정형하여 도체율에 따른 각각의 도체비율을 백분율로 구하였다.

육질분석은 정형된 가슴살 및 다리살을 각 처리구별로 5 수씩 선발하여 분석에 이용하였 다. 육색은 chromameter (Model CR-410, Minolta Co., Japan)를 사용하여 동일한 시료를 3회 반 복하여 명도 $\left(\mathrm{L}^{*}\right)$, 적색도 $\left(\mathrm{a}^{*}\right)$ 및 황색도 $\left(\mathrm{b}^{*}\right)$ 값 을 측정하였으며, 이때 표준색판은 $\mathrm{Y}=94.6$, $\mathrm{x}=0.3131, \mathrm{y}=0.3194$ 으로 하였다. $\mathrm{pH}$ 의 측정은 $\mathrm{pH}$ meter(77P, Istek, Korea)를 이용하였고, 드립 감량은 시료를 $2 \times 2 \times 2 \mathrm{~cm}$ 두께의 일정한 모양 으로 정형한 후 polyethylene bag에 넣어 $4{ }^{\circ} \mathrm{C}$ 냉 장실에서 7 일간 보관하면서 발생되는 감량을 측정하였다. 가열 감량 (cooking loss)은 시료를 $2 \mathrm{~cm}$ 두께로 일정하게 절단하여 무게를 측정 하고 $70^{\circ} \mathrm{C}$ 항온수조에서 10 분간 가열한 다음 냉각시켜 감량된 무게를 백분율로 환산하여 측 정하였다.

보수력(Water holding capacity)은 Hofmann 등 (1982)의 방법으로 전체면적과 육의 면적의 비 율을 기록하여 측정하였으며, 지방산패도(thiobarbituric acid reactive substances; TBARS) 분석 은 Witte 등(1970)에 의한 thiobarbituric acid (TBA)가 측정법을 이용하여 분석하였다.
(4) 지방산 분석

지방산 분석은 각 처리당 5수씩 정형한 다리 살, 가슴살 및 복강지방을 이용하였다. 지방 추 출은 Folch 등 (1957)의 방법으로 choroform과 methanol로 추출하였다. 시료 $10 \mathrm{~g}$ 을 시료의 5 10배 $\mathrm{CM}$ (choloform : methanol=2:1)에 2시간 추출한 후 분별깔대기에 filtering 하여 담고 $0.8 \% \mathrm{KCl}$ 을 첨가하여 5 분간 혼합한 후, 3,000 $\mathrm{rpm}$ 에서 10 분간 원심분리 시켰다. 하층은 funnel filter paper에 sodium anhydrous sulfate를 첨가하 여 filtering 하여 분리한 후 $45^{\circ} \mathrm{C}$ 에서 진공 농 축기로 농축하여 추출하였다. 추출한 지방은 $\mathrm{NaOH} / 0.5 \mathrm{~N}$ methanol $10 \mathrm{ml}$ 넣고 $80 \sim 90^{\circ} \mathrm{C}$ 에서 6 분간 반응, $14 \% \mathrm{BF} 35 \mathrm{ml}$ 넣고 반응 그리고 헥 산 $10 \mathrm{ml}$ 을 넣고 1 분간 반응 후 냉각시킨 후 포화 $\mathrm{NaCl}$ 을 넣어 반응을 종결 시킨 후 $\mathrm{GC} / \mathrm{FID}$ 로 분석하였다(Table 2).

Table 2. GC conditions for analysis of total fatty acids compositions

\begin{tabular}{lc}
\hline \multicolumn{1}{c}{ Items } & \multicolumn{1}{c}{ Conditions } \\
\hline \hline Instrument & $\begin{array}{c}\text { Hewlett Packard 5890 series } \\
\text { II Gas chromatography }\end{array}$ \\
\hline Column & VARIAN CP-SIL80(FAME) \\
\hline Flow & N2 \\
\hline Flow rate & FIDl (Flame Ionization \\
\hline Detector & Detector) \\
\hline Spilt & $100: 1$ \\
\hline Inlet Temperature & $220^{\circ} \mathrm{C}$ \\
\hline Detector Temperature & $240^{\circ} \mathrm{C}$ \\
\hline Initial Oven & $120^{\circ} \mathrm{C}$ \\
Temperature & $220^{\circ} \mathrm{C}$ \\
\hline Final oven temperature & \\
\hline
\end{tabular}

\section{(5) 콜레스테롤 분석}

가슴살, 다리살 및 복강지방 내 콜레스테롤 함량을 측정하기 위하여 각 처리당 5 수씩 가슴 살 및 다리살의 일부를 일정량의 $0.05 \mathrm{M}$ potassium phosphate buffer (pH 6.8)에 넣은 후에 균질기를 사용하여 균질액을 제조하였다. 이 균질액을 $4^{\circ} \mathrm{C}$ 에서 $2,000 \times \mathrm{g}$ 로 원심분리한 후 상층액을 분석에 이용하였다. 분리된 다리살 추출액은 
enzymatic colorimetric method에 의하여 총콜레 스테롤 검사시약(Boehringer Mannheim, Germany) 에 반응시켜 자동 생화학 분석기(Hitachi 747, Hitachi, Japan)를 이용하여 측정하였다.

\section{5. 통계처리}

모든 자료는 SAS (1996)의 General Linear Model procedure를 이용하여 Duncan's multiple range test(Duncan, 1955)로 처리하여 평균간의 유의성을 검정하였다.

\section{III. 결과 및 고찰}

\section{1. 생산성}

육계에 있어서 잣 부산물의 급여가 증체량, 사료섭취량 및 사료요구율에 미치는 영향은 Table 3에 나타내었다. 전체 시험기간 동안 증 체량, 사료섭취량 및 사료요구율은 처리구간에 유의적인 차이가 없었다.

길용현 (2006)은 육계에 잣송이 부산물을 사 료 내 첨가하여 급여 시 전체 시험기간 동안 증체량 및 사료 요구율은 처리구간에 유의적인 차이가 없었다고 보고하여 본 시험과 유사한
결과를 나타내었으나, 사료섭취량은 잣송이 부 산물을 첨가한 처리구가 대조구 보다 높게 나 타나 본 시험과 상이한 결과를 나타내었다.

본 시험의 결과 잣 부산물의 첨가는 육계의 생산성에 영향을 미치지 않았으며, 길용현 (2006)의 보고에서 본 시험과 사료섭취량의 상 이한 결과는 미루나무 톱밥의 첨가 및 부산물 의 첨가 수준 차이에 기인된 것으로 사료된다.

\section{2. 혈액성상}

육계에 있어서 잣 부산물의 급여가 혈액성상 에 미치는 영향은 Table 4에 나타내었다. HDL cholesterol의 함량은 처리구간에 유의적인 차이 가 없었으며, total cholesterol 및 $\mathrm{LDL}$ cholesterol은 PCM1.0 처리구가 다른 처리구와 비교하여 유의적인 차이는 없었으나 낮은 경향 을 나타내었다. Triglyceride의 함량은 잣 부산 물을 첨가한 $\mathrm{PCM} 0.5$ 및 $\mathrm{PCM} 1.0$ 처리구가 $\mathrm{CS}$ 처리구와 비교하여 유의적인 차이는 없었으나 낮은 경향을 나타내었다.

$\mathrm{LDL}$-콜레스테롤은 동맥경화증, 고혈압 등의 심혈관 질환의 요인이 되는 과유지질혈증을 구 성하는 주된 원인 물질로서(Baker 등, 1984), 관상동맥 질환을 유발시키는 위험인자로 알려

Table 3. Effects of dietary pine cone meal on growth performance in broiler

\begin{tabular}{|c|c|c|c|c|}
\hline Items & $\mathrm{CS}^{1)}$ & PCM0.5 $5^{1)}$ & PCM1.0 ${ }^{1)}$ & $\mathrm{SE}^{2)}$ \\
\hline \multicolumn{5}{|l|}{ "0 2 weeks } \\
\hline Weight gain (g) & 311.25 & 313.99 & 312.82 & 6.04 \\
\hline Feed intake (g) & 420.32 & 421.30 & 416.25 & 5.01 \\
\hline Feed/Gain & 1.35 & 1.34 & 1.33 & 0.02 \\
\hline \multicolumn{5}{|l|}{ 2 5 weeks } \\
\hline Weight gain (g) & 1326.22 & 1316.42 & 1363.55 & 30.48 \\
\hline Feed intake (g) & 2427.02 & 2382.48 & 2442.20 & 29.25 \\
\hline Feed/Gain & 1.83 & 1.81 & 1.79 & 0.02 \\
\hline \multicolumn{5}{|l|}{ Overall } \\
\hline Weight gain (g) & 1637.48 & 1633.75 & 1676.38 & 33.32 \\
\hline Feed intake (g) & 2847.34 & 2803.16 & 2858.45 & 28.04 \\
\hline Feed/Gain & 1.74 & 1.72 & 1.71 & 0.04 \\
\hline
\end{tabular}


Table 4. Effects of dietary pine cone meal on serum cholesterol concentrations in broiler

\begin{tabular}{lrrrc}
\hline Items (mg/dL) & \multicolumn{1}{c}{$\mathrm{CS}^{1)}$} & $\mathrm{PCM}^{1} .5^{1)}$ & $\mathrm{PCM}^{1.0^{1)}}$ & $\mathrm{SE}^{2)}$ \\
\hline \hline Total cholesterol & 193.60 & 191.60 & 167.20 & 20.45 \\
HDL cholesterol $^{3)}$ & 108.60 & 100.20 & 100.80 & 4.19 \\
LDL cholesterol $^{4)}$ & 67.00 & 72.40 & 41.60 & 16.93 \\
Triglyceride & 103.40 & 76.60 & 82.80 & 18.89 \\
\hline
\end{tabular}

${ }^{1)} \mathrm{CS}$; added cottonwood sawdust $1 \%$, PCM0.5; added cottonwood sawdust $0.5 \%+$ pine cone meal $0.5 \%$ and PCM1.0; added pine cone meal $1 \%$.

${ }^{2)}$ Pooled standard error.

${ }^{3)}$ High density lipoprotein cholesterol.

${ }^{4)}$ Low density lipoprotein cholesterol.

져 있다. 반면에 HDL-콜레스테롤은 apoprotein$\mathrm{A}$ 의 작용에 의해 $\mathrm{LDL}$ 섭취를 억제시키는 작용 이 있는 것으로 보고(Leon 등, 1979; Kannel 등, 1979; Goldberg 등, 1985)되고 있어 관상동맥 질 환의 예방인자로 알려져 있다.

길용현(2006)은 육계에 잣송이 부산물을 첨가 하여 급여시 대조구와 비교하여 잣송이 부산물 을 급여한 처리구가 혈중 콜레스테롤 농도가 낮게 나타나 본 시험과 유사한 경향을 나타내 었다. 잣의 지방산은 대부분 불포화지방산으로 구성되어 있으며, terpinolene과 borneol 성분은 콜레스테롤 수치를 낮추어 주는 작용을 하는 것으로 알려져 있다 $(\mathrm{Kim}$ 등, 1984; Kim 등, 1986).

본 시험에서는 잣 부산물을 $1 \%$ 급여한 처리 구가 총 콜레스테롤과 LDL-콜레스테롤이 감소 하는 경향이 나타났으나 유의적인 차이는 나타 나지 않았으며, 이러한 결과는 잣 부산물에 함 유된 성분 중 콜레스테롤 수치를 감소시키는
유효성분의 수준이 낮았기 때문으로 사료된다.

\section{3. 도체특성}

육계에 있어서 잣 부산물의 급여가 도체특성 에 미치는 영향은 Table 5에 나타내었다. 도체 율, 가슴살 및 다리살의 도체비율은 처리구간 에 유의적인 차이가 없었으며, 복강지방의 비 율은 잣 부산물을 급여한 처리구가 $\mathrm{CS}$ 처리구 와 비교하여 유의적인 차이는 없었으나 낮은 경향을 나타내었으나 통계적인 차이는 보이지 않았다.

육계에서 생시 체중의 $15 \sim 20 \%$ 를 차지하는 도체지방은 주로 피하나 혹은 복강주변에 축적 되며 (Griffin과 Whitehead, 1982; Leenstra, 1982), 도계 처리장 및 소비자의 생산성과 기호성을 저하시키는 요인이다. 길용현 (2006)은 잣송이 부산물을 이용한 육계 실험에서 복강지방 비율 은 잣송이 부산물 $1 \%$ 첨가구를 제외한 $\mathrm{CS}$ 및

Table 5. Effects of dietary pine cone meal on carcass characteristic in broiler

\begin{tabular}{lcccc}
\hline Items & $\mathrm{CS}^{1)}$ & PCM0.5 & PCM1.0 $^{1)}$ & $\mathrm{SE}^{2)}$ \\
\hline \hline Live weight (g) & 1682 & 1647 & 1721 & 33.30 \\
Carcass (\%) & 74.17 & 74.03 & 74.52 & 0.52 \\
Leg meat (\%) & 8.28 & 8.22 & 8.34 & 0.19 \\
Breast meat (\%) & 17.25 & 16.23 & 16.48 & 0.90 \\
Abdominal fat pad (\%) & 2.41 & 2.15 & 1.90 & 0.17 \\
\hline
\end{tabular}

${ }^{1)} \mathrm{CS}$; added cottonwood sawdust $1 \%$, PCM0.5; added cottonwood sawdust $0.5 \%+$ pine cone meal $0.5 \%$ and PCM1.0; added pine cone meal $1 \%$.

${ }^{2)}$ Pooled standard error. 
PCM0.5 처리구에서 유의적인 차이는 없었으나 낮아지는 경향이 나타났다고 보고하였다.

본 시험에서는 유의적인 차이는 없었으나 체 중에 대한 복강지방의 함량이 잣 부산물을 급 여한 처리구에서 낮아지는 경향이 나타났으며, 이러한 결과는 혈중 triglyceride 함량이 낮게 나 타난 경향과 관련성이 있는 것으로 사료된다.

\section{4. 육질특성}

육계에 있어서 잣 부산물의 급여가 다리살 및 가슴살의 계육특성에 미치는 영향은 Table 6 에 나타내었다. 다리살의 육질특성에서 TBARS 는 CS 처리구가 PCM1.0 처리구와 비교하여 유 의적으로 높게 나타났으며 $(P<0.05)$, 육색, 드립 감량, $\mathrm{pH}$, 조리감량 및 보수력은 처리구간에 유의적인 차이가 없었다. 가슴살의 육질특성에 서 TBARS는 CS 처리구가 PCM1.0 처리구와
비교하여 유의적으로 높게 나타났으며 $(P<0.05)$, 육색, 드립감량, $\mathrm{pH}$, 조리감량 및 보수력은 처 리구간에 유의적인 차이가 없었다.

$\mathrm{Kim}$ 등(1988)은 잣 지방질에는 산화 반응에 억제 기능을 가지고 있는 천연 항산화 물질이 함유되어 있는 것으로 추정되어진다고 보고하 였고, 잣 지방질의 산화 안정성 시험에서 잣에 함유된 항산화제인 토코페롤 및 카로티노이드 함량 측정결과 자동산화가 진행되는 동안 카로 티노이드와 토코페롤이 감소하였고, 초기과정 에서 항산화제로 작용하여 상당량이 감소되었 다고 보고 하였다(Kim, 1993).

본 시험의 결과 잣 부산물의 급여는 TBARS 에 영향을 미쳤으며, 잣 부산물에 함유된 천연 항산화제 효과에 의해 TBARS가 감소된 것으 로 사료된다.

\section{5. 지방산 조성}

Table 6. Effects of dietary pine cone meal on leg meat and breast meat quality in broiler

\begin{tabular}{|c|c|c|c|c|c|c|c|c|}
\hline \multirow{2}{*}{ Items } & \multicolumn{4}{|c|}{ Leg meat } & \multicolumn{4}{|c|}{ Breast meat } \\
\hline & $\mathrm{CS}^{1)}$ & PCM0. $5^{1)}$ & PCM1.0 $0^{1)}$ & $\mathrm{SE}^{2)}$ & $\mathrm{CS}^{1)}$ & PCM0. $5^{1)}$ & PCM1.0 $0^{1)}$ & $\mathrm{SE}^{2)}$ \\
\hline \multicolumn{9}{|l|}{$\mathrm{CIE}^{3)}$} \\
\hline Lightness $\left(\mathrm{L}^{*}\right)$ & 54.87 & 53.66 & 52.11 & 2.00 & 54.78 & 47.30 & 50.79 & 3.38 \\
\hline Redness $\left(\mathrm{a}^{*}\right)$ & 16.67 & 16.60 & 16.07 & 0.61 & 15.06 & 16.41 & 14.16 & 0.90 \\
\hline Yellowness $\left(\mathrm{b}^{*}\right)$ & 8.79 & 9.42 & 8.44 & 0.75 & 12.57 & 11.24 & 11.53 & 1.32 \\
\hline \multicolumn{9}{|l|}{ Drip loss (\%) } \\
\hline 1 day & 1.39 & 1.39 & 1.20 & 0.15 & 3.13 & 3.82 & 3.25 & 0.92 \\
\hline 3 days & 2.30 & 1.96 & 2.08 & 0.18 & 5.52 & 5.53 & 5.51 & 1.16 \\
\hline 5 days & 3.40 & 2.89 & 3.06 & 0.19 & 6.73 & 6.82 & 6.84 & 1.10 \\
\hline 7 days & 4.07 & 3.48 & 3.51 & 0.20 & 8.91 & 8.55 & 8.50 & 1.20 \\
\hline $\mathrm{pH}$ & 6.16 & 6.31 & 6.36 & 0.11 & 5.75 & 5.75 & 5.87 & 0.07 \\
\hline Cook loss $(\%)$ & 32.64 & 32.98 & 31.39 & 2.97 & 34.72 & 31.09 & 30.26 & 1.45 \\
\hline $\mathrm{WHC}^{4)}(\%)$ & 48.67 & 45.12 & 46.14 & 4.01 & 48.05 & 57.51 & 55.19 & 5.03 \\
\hline TBARS $^{5)}(\mathrm{mgMA} / \mathrm{kg})$ & $0.025^{\mathrm{a}}$ & $0.020^{\mathrm{ab}}$ & $0.014^{\mathrm{b}}$ & 0.002 & $0.030^{\mathrm{a}}$ & $0.022^{\mathrm{ab}}$ & $0.021^{\mathrm{b}}$ & 0.003 \\
\hline
\end{tabular}

1) $\mathrm{CS}$; added cottonwood sawdust 1\%, PCM0.5; added cottonwood sawdust $0.5 \%+$ pine cone meal $0.5 \%$ and PCM1.0; added pine cone meal $1 \%$.

2) Pooled standard error.

3) Commision Internationale de L'eclairage.

4) Water Holding Capacity.

5) thiobarbituric acid reactive substances.

a,b Means in the same row with different superscripts differ $(P<0.05)$. 
육계에 있어서 잣 부산물의 급여가 다리살, 가슴살 및 복강지방의 지방산 조성에 미치는 영향은 Table 7, Table 8 및 Table 9에 나타내었 다. 다리살의 지방산 조성에 있어서 arachidate 는 PCM0.5 처리구가 PCM1.0 처리구와 비교하 여 유의적으로 높게 나타났으며, linolenate는 PCM1.0 처리구가 다른 처리구와 비교하여 가 장 낮게 나타났다 $(P<0.05)$. Total saturated fatty acid (SFA), total monounsaturated fatty acids (MUFA), total poly unsaturated Fatty Acid (PUFA) 및 total unsaturated fatty acid(UFA)/SFA
는 처리구간에 유의적인 차이가 없었다 $(P>$ 0.05). 가슴살 및 복강지방의 지방산 조성에 있 어서 total SFA, total MUFA, total PUFA, total $\mathrm{UFA} / \mathrm{SFA}$ 및 지방산은 처리구간에 유의적인 차 이가 없었다.

Shin 등(1998)은 계육의 지방산 조성은 oleic acid, palmitic acid, linoleic acid, stearic acid 순 으로 나타났다고 보고 하였으며, 본 시험의 결 과와 비슷한 경향이었다. $\operatorname{Hood}(1984)$ 는 닭, 돼 지 등 단위 동물의 지방산 조성은 급여되는 사 료의 지방산 조성에 따라 영향을 받는다고 보

Table 7. Effects of dietary pine cone meal on fatty acid composition of leg meat in broiler

\begin{tabular}{|c|c|c|c|c|}
\hline \multirow{2}{*}{ Fatty acid (\%) } & \multicolumn{4}{|c|}{ Leg meat } \\
\hline & $\mathrm{CS}^{1)}$ & PCM0. $5^{1)}$ & PCM1.0 $0^{1)}$ & $\mathrm{SE}^{2)}$ \\
\hline Myristate (C14:0) & 1.04 & 1.12 & 1.07 & 0.05 \\
\hline palmitate (C16:0) & 19.34 & 18.98 & 19.19 & 0.34 \\
\hline Stearate (C18:0) & 9.56 & 8.58 & 9.07 & 0.70 \\
\hline Arachidate $(\mathrm{C} 20: 0)$ & $0.28^{\mathrm{ab}}$ & $0.32^{\mathrm{a}}$ & $0.25^{\mathrm{b}}$ & 0.02 \\
\hline Myristoleate (C14:1n5 ) & 0.23 & 0.25 & 0.29 & 0.03 \\
\hline palmitoleate $(\mathrm{C} 16: \ln 7)$ & 3.71 & 4.24 & 4.14 & 0.60 \\
\hline Oleate (C18:1n9) & 26.40 & 27.25 & 25.47 & 1.46 \\
\hline Eicosenoate $(\mathrm{C} 20: \ln 9)$ & 0.56 & 0.60 & 0.61 & 0.04 \\
\hline Erudate $(\mathrm{C} 22: \ln 9)$ & 4.92 & 4.44 & 4.34 & 0.56 \\
\hline Nervonate (C24:1n9) & 0.27 & 0.36 & 0.36 & 0.05 \\
\hline Total MUFA & 36.09 & 37.14 & 35.21 & 1.72 \\
\hline Linoleate (C18:2n6) & 15.86 & 15.41 & 16.30 & 0.62 \\
\hline Eicosadienoate (C20:2n6) & 0.25 & 0.26 & 0.27 & 0.03 \\
\hline Arachidonate (C20:4n6) & 0.45 & 0.43 & 0.54 & 0.08 \\
\hline Total $\omega 6$ & 16.56 & 16.10 & 17.11 & 0.68 \\
\hline Linolenate (C18:3n3) & $0.04^{\mathrm{a}}$ & $0.04^{\mathrm{a}}$ & $0.02^{\mathrm{b}}$ & 0.01 \\
\hline Docosahexaenoate (C22:6n3) & 0.27 & 0.36 & 0.36 & 0.05 \\
\hline Total $\omega 3$ & 0.31 & 0.40 & 0.38 & 0.05 \\
\hline Total $\omega 6 / \omega 3$ & 43.18 & 45.75 & 40.58 & 2.65 \\
\hline Total PUFA & 16.87 & 16.50 & 17.49 & 0.69 \\
\hline Total SFA & 30.21 & 29.00 & 29.59 & 0.50 \\
\hline Total UFA & 52.95 & 53.63 & 52.70 & 1.20 \\
\hline Total UFA/SFA & 1.76 & 1.85 & 1.79 & 0.07 \\
\hline
\end{tabular}


Table 8. Effects of dietary pine cone meal on fatty acid composition of breast meat in broiler

\begin{tabular}{|c|c|c|c|c|}
\hline \multirow{2}{*}{ Fatty acid (\%) } & \multicolumn{4}{|c|}{ Breast meat } \\
\hline & $\mathrm{CS}^{1)}$ & PCM0. $5^{1)}$ & PCM1.. $0^{1)}$ & $\mathrm{SE}^{2)}$ \\
\hline Myristate (C14:0) & 0.89 & 0.85 & 0.92 & 0.10 \\
\hline palmitate $(\mathrm{C} 16: 0)$ & 19.19 & 18.99 & 18.37 & 0.89 \\
\hline Stearate $(\mathrm{C} 18: 0)$ & 9.05 & 9.31 & 9.72 & 0.52 \\
\hline Arachidate (C20:0) & 0.31 & 0.28 & 0.26 & 0.02 \\
\hline Myristoleate (C14:1n5) & 0.17 & 0.15 & 0.12 & 0.02 \\
\hline palmitoleate $(\mathrm{C} 16: 1 \mathrm{n} 7)$ & 2.63 & 2.58 & 2.05 & 0.40 \\
\hline Oleate $(\mathrm{C} 18: \ln 9)$ & 23.93 & 24.57 & 22.67 & 1.51 \\
\hline 11-Eicosenoate (C20:1n9) & 0.50 & 0.48 & 0.42 & 0.07 \\
\hline Erudate (C22:1n9) & 5.49 & 5.44 & 5.96 & 0.76 \\
\hline Nervonate (C24:1n9) & 0.50 & 0.56 & 0.50 & 0.05 \\
\hline Total MUFA & 33.21 & 33.78 & 31.71 & 1.32 \\
\hline Linoleate (C18:2n6) & 14.56 & 14.56 & 14.95 & 0.51 \\
\hline Eicosadienoate (C20:2n6) & 0.47 & 0.39 & 0.46 & 0.05 \\
\hline Arachidonate (C20:4n6) & 1.04 & 0.67 & 0.93 & 0.13 \\
\hline Total $\omega 6$ & 16.07 & 15.63 & 16.34 & 0.60 \\
\hline Linolenate (C18:3n3) & 0.00 & 0.01 & 0.02 & 0.01 \\
\hline Docosahexaenoate (C22:6n3) & 0.50 & 0.56 & 0.50 & 0.06 \\
\hline Total $\omega 3$ & 0.50 & 0.57 & 0.52 & 0.05 \\
\hline Total $\omega 6 / \omega 3$ & 33.27 & 28.70 & 33.37 & 3.44 \\
\hline Total PUFA & 16.57 & 16.19 & 16.85 & 0.60 \\
\hline Total SFA & 29.44 & 29.43 & 29.27 & 0.54 \\
\hline Total UFA & 49.78 & 49.97 & 48.56 & 1.04 \\
\hline Total UFA/SFA & 1.69 & 1.70 & 1.66 & 0.04 \\
\hline
\end{tabular}

${ }^{1)} \mathrm{CS}$; added cottonwood sawdust $1 \%$, PCM0.5; added cottonwood sawdust $0.5 \%+$ pine cone meal $0.5 \%$ and PCM1.0; added pine cone meal $1 \%$.

${ }^{2)}$ Pooled standard error.

고 하였으나, 본 시험에서는 잣에 함유된 지방

산 중 가장 풍부한 지방산인 Linoleate 함량에 는 영향을 미치지 않았다.

\section{6. 콜레스테롤 함량}

육계에 있어서 잣 부산물의 급여가 다리살, 가슴살 및 복강지방의 콜레스테롤 함량에 미치 는 영향은 Table 10에 나타내었다. 다리살, 가 슴살 및 복강지방의 콜레스테롤 함량은 유의적
인 차이는 없었으나 잣 부산물의 첨가수준이 증가할수록 콜레스테롤 함량이 감소하는 경향 이 나타났으며, 복강지방은 유의적인 차이가 나타나지 않았다. 이우진 등 (2006)은 육계에 잣 송이 추출물 급여시 가슴살의 콜레스테롤은 유 의적으로 감소하였고, 다리살에서는 처리구가 감소하는 경향을 보였으나 유의적인 차이는 나 타나지 않아 본 시험과 유사한 경향을 나타내 었다.

본 연구에서 잣 부산물의 급여는 다리살과 
Table 9. Effects of dietary pine cone meal on fatty acid composition of abdomen fat in broiler

\begin{tabular}{|c|c|c|c|c|}
\hline \multirow{2}{*}{ Fatty acid (\%) } & \multicolumn{4}{|c|}{ Abdomen fat } \\
\hline & $\mathrm{CS}^{1)}$ & PCM0. $5^{1)}$ & PCM1.0 $0^{1)}$ & $\mathrm{SE}^{2)}$ \\
\hline Myristate (C14:0) & 1.24 & 1.26 & 1.23 & 0.02 \\
\hline palmitate $(\mathrm{C} 16: 0)$ & 22.44 & 22.24 & 22.08 & 0.37 \\
\hline Stearate $(\mathrm{C} 18: 0)$ & 6.16 & 5.99 & 5.96 & 0.24 \\
\hline Arachidate (C20:0) & 0.45 & 0.46 & 0.46 & 0.01 \\
\hline Myristoleate (C14: $\ln 5)$ & 0.28 & 0.27 & 0.27 & 0.02 \\
\hline palmitoleate $(\mathrm{C} 16: \ln 7)$ & 5.07 & 5.06 & 5.13 & 0.16 \\
\hline Oleate $(\mathrm{C} 18: \ln 9)$ & 40.12 & 40.91 & 40.70 & 0.52 \\
\hline Eicosenoate $(\mathrm{C} 20: \ln 9)$ & 0.91 & 0.91 & 0.94 & 0.03 \\
\hline Erudate (C22:1n9) & 0.13 & 0.10 & 0.10 & 0.02 \\
\hline Total MUFA & 46.51 & 47.26 & 47.14 & 0.57 \\
\hline Linoleate (C18:2n6) & 12.66 & 13.01 & 13.40 & 0.28 \\
\hline Eicosadienoate (C20:2n6) & 0.27 & 0.24 & 0.27 & 0.01 \\
\hline Arachidonate (C20:4n6) & 0.16 & 0.13 & 0.16 & 0.02 \\
\hline Total w6 & 13.08 & 13.39 & 13.08 & 0.29 \\
\hline Linolenate (C18:3n3) & 0.37 & 0.39 & 0.43 & 0.02 \\
\hline Total w3 & 0.37 & 0.39 & 0.43 & 0.02 \\
\hline Total w6/w3 & 35.02 & 35.32 & 35.51 & 0.35 \\
\hline Total PUFA & 13.46 & 13.77 & 14.25 & 0.30 \\
\hline Total SFA & 30.29 & 29.95 & 29.73 & 0.51 \\
\hline Total UFA & 59.96 & 61.03 & 61.39 & 0.67 \\
\hline Total UFA/SFA & 1.98 & 2.04 & 2.07 & 0.05 \\
\hline
\end{tabular}

${ }^{1)} \mathrm{CS}$; added cottonwood sawdust $1 \%$, PCM0.5; added cottonwood sawdust $0.5 \%+$ pine cone meal $0.5 \%$ and PCM1.0; added pine cone meal $1 \%$.

${ }^{2)}$ Pooled standard error.

Table 10. Effect of dietary pine cone meal on cholesterol contents of leg, breast meat and abdomen fat in broiler

\begin{tabular}{lrrrr}
\hline Items & $\mathrm{CS}^{1)}$ & PCM0.5 & PCM1.0 $^{1)}$ & $\mathrm{SE}^{2)}$ \\
\hline \hline Cholesterol $(\mathrm{mg} / 100 \mathrm{~g})$ & & & & \\
Leg meat & 8.81 & 8.52 & 7.67 & 0.43 \\
Breast meat & 5.52 & 5.20 & 4.83 & 0.33 \\
Abdomen fat pad & 21.05 & 22.03 & 24.38 & 1.16 \\
\hline
\end{tabular}

${ }^{1)} \mathrm{CS}$; added cottonwood sawdust $1 \%$, PCM0.5; added cottonwood sawdust $0.5 \%+$ pine cone meal $0.5 \%$ and PCM1.0; added pine cone meal $1 \%$.

${ }^{2)}$ Pooled standard error.

가슴살의 콜레스테롤 함량이 감소하는 경향을 나타내었으나 유의적인 차이는 없었으며, 복강 지방에는 영향을 미치지 못했다.

본 시험의 결과 육계에 잣 부산물 급여는 TBARS에 영향을 미치는 것으로 사료된다.
IV. 요 약

본 연구는 잣 부산물의 급여가 육계의 생산 성, 혈청 콜레스테롤, 도체특성 및 육의 지방산 과 콜레스테롤 함량에 미치는 영향을 알아보기 
위하여 시험을 실시하였다. 사양시험은 2 일령 Arbor Acre Broiler(令) 480수를 공시하였으며, 5 주간 사양시험을 실시하였다. 시험설계는 1 ) $\mathrm{CS}$ (미루나무톱밥 1\%), 2) $\mathrm{PCM} 0.5$ (잣 부산물 $0.5 \%$ + 미루나무톱밥 $0.5 \%$ ) 및 3 ) $\mathrm{PCM} 1.0$ (잣 부산물 $1 \%$ )로 3 개 처리를 하여 처리당 8 반복, 반복당 20 수씩 완전임의 배치하였다. 전체 시 험 기간 동안 생산성은 처리구간에 유의적인 차이가 없었으며 $(P>0.05)$, 또한, 혈청 콜레스테 롤 및 도체비율도 처리구간에 유의적인 차이가 없었다 $(P>0.05)$. 다리살과 가슴살의 TBARS는 PCM1.0 처리구가 CS 처리구와 비교하여 유의적 으로 높았다 $(P<0.05)$. 다리살의 arachidate는 $\mathrm{PCM} 0.5$ 처리구가 PCM1.0 처리구와 비교하여 유의적으로 높게 나타났으며, linolenate는 PCM1.0 처리구가 다른 처리구와 비교하여 가 장 낮게 나타났다 $(P<0.05)$. 다리살, 가슴살 및 복강지방의 콜레스테롤 함량은 처리구간에 유 의적인 차이가 없었다 $(P>0.05)$. 결론적으로 본 시험의 결과 육계에 잣 부산물의 급여는 TBARS에 영향을 미치는 것으로 사료된다.

\section{$\mathrm{V}$. 인 용 문 헌}

1. Allian, C. C., Poon, L. S., Chan, C. S. G., Richmond, W. and Fu, P. C. 1974. Enzymatic determination of total serum cholesterol. Clin. Chem. 20:470-475.

2. Baker, H. J., Lindsey, J. R. and Weisbroth, S. H. 1984. The laboratory rat. Academic Press Inc New York. 2:123-131.

3. Baricevic, D., Milevoj, L. and Borstnik, J. B. 2001. Insecticidal effect of oregano Origanum vulgare L. ssp. hirtum Inter. J. Horticult. Sci. 7: 84-88.

4. Cimanga, K., Kambu, K., Tona, L., Apers, S., De Bruyne, T., Hermans, N., Totte J., Pieters, L. and Vlietinck, A. J. 2002. Correlation between chemical composition and antibacterial activity of essential oils of some aromatic medicinal plants growing in the Democratic Republic of Congo. J. Ethnopharmacol. 79:213-220.
5. Duncan, D. B. 1955. Multiple range and multiple F tests. Biometrics. 11:1-14.

6. Folch, J., Lees, M. and Sloane Stanley, G. H. 1957. A simple method for the isolation and purification of total lipid from animal tissues. J. Bio. Chem. 226:497-509.

7. Goldberg, L. and Diane, L. Elliot. 1985. The effect of physical activity on lipid and lipoprotein levels. Medicine Clinics of North America. 69(1):41-55.

8. Griffin, H. D. and Whitehead, C. C. 1982. Plasma lipoprotein concentration as an indicator of fatness in broilers: development and use of a simple assay for plasma very low density lipoproteins. Brit. Poult. Sci. 23:307-313.

9. Hofmann, K., Hamm, R. and Bluchel, E. 1982. New information on the determination of water binding in meat by the filter paper press method. Fleischwirtsch. 62:87-94.

10. Hood, R. L. 1984. Cellular and biochemical aspects of fat deposition in the broiler chicken. Poult. Sci. 40:160-164.

11. Hong, W. T., Go, G. M., Lee, J. G., Jang, H. J. and Kwag, J. J. 2002. Volatile compounds of pine needle (Pinus rigida Miller) extract. Journal of Korea Society of Tobacco Science. 24(1):53-59.

12. Kannel, W. B., Tavia, Gordon, William, P. and Castelli. 1979. Obesity lipids and glucose intolerance (The Framingham study). The American J. Clin. Nutrition. 32:1238-1244.

13. Kim, M. 1993. Changes in the concentration of tocopherol and carotenoid in pinenut oil during autoxidation. J. Korean Soc. Food Nutr. 21(1): 96-100.

14. Kim, M., Lee, S. H., Yoo, J. H. and Choi, H. S. 1988. Studies on the oxidative Stability of pinenut oil. Korean J. Food Sci. Technol. 20(6):868-872.

15. Kim, M., Rhee, S. H. and Cheigh, H. S. 1984. Lipid Contents and fatty acid composition of three lipid classes in korean pinenut. J. Korean Soc. Food Nutr. 13(4):406-412.

16. Kim, Y. K., Chung, K. N., Hirosh Ishi and 
Shigeru Muraki. 1986. Volatile components of pinenut. Korea J. Food Sci. Technol. 18(2):105109.

17. Kwak, W. S. and Yoon, J. S. 2003. On-site output survey and feed value evaluation on agroindustrial by-products. Korean J. Anim. Sci. \& Technol. (Kor.) 45(2):251-264.

18. Leenstra, F. R. 1982. Genetic aspects of fat deposition and feed efficiency. 24'th British Poultry Breeder's Roundtable Conference, Edinburgh, Scotland.

19. Leon, A. S., John, C. and Donald, B. H. 1979. Effect of a vigorous walking program on body composition and carbohydrate and lipid metabolism of boiese young men. The Am. J. Clin. Nutrition. 32:1776-1787.

20. Lim, Y. S., Park, K. N., Bae, M. J. and Lee, S. H. 2001. Antimicrobial effects of pinus densiflora Sieb. et Zucc. extract on pathogenic microorganisms. Korean J. Postharvest Sci Technol. 8(4):462-468.

21. Naoyuki, N. and Yoshiharu, F. 1995. The elevation of plasma concentration of high-density lipoprotein cholesterol in mice fed with protein from proso millet. Biosci. Biotech. Biochem. 59: 333-335.

22. Park, Y. S. and Chung, M. S. 2005. Cholesterollowering effect of pine nut in plasma of rat. Korean J. Food Sci. Technol. 37(5):702-708.

23. SAS 1996. SAS user's guide: Statisics, SAS Inst, Inc., Cary, NC.
24. Shin, K. K., Park, H. I., Lee, S. K. and Kim, C. J. 1998. Studies on fatty acids composition of different portions in various meat. Kor. J. Food Sci. 18(3):261-268.

25. Witte, V. C., Krause, G. F., Bailey, M. E. 1970. A new extraction method for determining 2thiobarbituric acid values for pork and beef during storage. J. Food Sci. 35:582-587.

26. Yang, J. K., Kang, B. K., Kim, T. H., Hong, S. C., Seo, W. T. and Choi, M. S. 2002. Efficient extraction methods and analysis of essential oil from softwood leaves. Korean J. Biotechnol. Bioeng. 17(4):357-364.

27. 고용균, 신종서, 김창혁, 홍병주, 박재인, 라창식. 2006. 잣송이를 이용한 축사환경개선제 및 사료 첨가제 개발에 관한 연구보고서. 강원대학교 농 림부.

28. 길용현. 2006. 잣송이 부산물 첨가급여가 브로일 러와 육성돈의 생산성에 미치는 영향. 강원대학 교 석사 학위논문.

29. 농림부. 2006. 산림청 임업통계연보. 제 36 호 pp. 296.

30. 이우진, 박재인, 김창혁, 이규호. 2006. 생리활성 추출물의 첨가급여가 육계의 성장능력과 혈청 및 고기의 콜레스테롤 함량, 지질산화에 미치는 영향. 제 22 차 한국가금학회 정기총회 및 학술발 표회. pp. 72-73.

31. 천석조, 박영호. 1984. 잣기름의 Triglyceride 조 성. 한국식품과학회지. 16(2):179-181.

(접수일자 : 2007. 8. 10. / 채택일자 : 2008. 1. 28.) 